\title{
Researches Regarding the Values of Some Electrocardiogram'S Components in Cats
}

\author{
Cristian BROJBĂ $\breve{1}^{*}$ \\ ${ }^{1}$ Faculty of Veterinary Medicine, University of Agronomic Sciences and Veterinary Medicine of Bucharest, \\ Splaiul Independenței 105, District 5, Zip code 050097, Bucharest, Romania \\ *corresponding author: cristian.brojba@gmail.com
}

Bulletin UASVM Veterinary Medicine 75(1)/2018

Print ISSN 1843-5270; Electronic ISSN 1843-5378

doi:10.15835/buasvmcn-vm:004817

\begin{abstract}
The electrocardiogram (ECG or EKG) represents the graphical recording of the cardiac electrical activity (Ghiță et al., 2005) and it is useful in the diagnosis in some cardiac diseases (such as rhythm disorders) (Cotor and Ghiţă, 2014) or frequency disorders (Ghiță et al., 2007).

The main target of this research work was to determine the values of the main components of the ECG and the cardiac frequency. The biological material was represented by 12 healthy cats of different breeds. The values obtained in this research work can be used as reference values in ECG interpretation in cats.
\end{abstract}

Keywords: cat, electrocardiogram, values

\section{Introduction}

The electrocardiogram (ECG or EKG) represents the graphical recording of the cardiac electrical activity (Ghiță et al., 2005). It is being composed of several components (waves, segments and intervals), each one of these has a functional significance. In this research we intended to determine the main ECG component's durations ( $\mathrm{P}$ wave, $\mathrm{P}-\mathrm{R}$ segment, $\mathrm{QRS}$ complex, Q-T interval, $\mathrm{T}$ wave) and the cardiac frequency in cats. We consider this research work to be important, because the studied ECG's parameters can be changed in some cardiac diseases (such as rhythm disorders) (Cotor and Ghiță, 2014) or frequency disorders (Ghiţă et al., 2007).

\section{Materials and methods}

The biological material was represented by 12 healthy cats of different breeds. The working method consisted in registration of the ECG in right lateral recumbency (Ghiță et al., 2005) using the following parameters: $10 \mathrm{~mm}$ for millivolt's amplitude and $50 \mathrm{~mm} / \mathrm{sec}$ for speed recording. The registration of the ECG was realized after 2-3 minutes from electrodes attachement, because we considered that this time was enough for relaxation of the animal andinstallation of the neurovegetative balance. The electrocardiograms were registered using Nikon Kohden electrocardiograph.

\section{Results and discussions}

In our research work we determined the durations of the most important components of the ECG, such as $\mathrm{P}$ wave (atrial depolarization), P-R segment (atrial electrical systole), QRS complex (ventricular depolarization), QT interval (ventricular electrical systole) and $T$ wave (the end of the ventricular repolarisation) and the cardiac frequency calculated on the basis R-R interval (Table 1). The average values of the ECG component durations obtained by us fall within the limits of the results acquired by other researchers (Table 2). 
Table 1. The values of the ECG components in cats, obtained by us (seconds)

\begin{tabular}{|c|c|c|c|c|c|c|c|c|}
\hline Nr. & Breed & Age & $\mathrm{P}$ & P-R (P-Q) & QRS & Q-T & $\mathrm{T}$ & Heart rate \\
\hline 1 & Persian & 1 year & 0,04 & 0,08 & 0,04 & 0,16 & 0,06 & 187,50 \\
\hline 2 & Siamese & 2 years & 0,04 & 0,08 & 0,04 & 0,12 & 0,08 & 187,50 \\
\hline 3 & European & 3 years & 0,04 & 0,08 & 0,06 & 0,16 & 0,06 & 166,66 \\
\hline 4 & European & 1 year & 0,06 & 0,08 & 0,04 & 0,16 & 0,06 & 214,28 \\
\hline 5 & Siamese & 3 years & 0,04 & 0,04 & 0,04 & 0,16 & 0,04 & 187,50 \\
\hline 6 & Turkish Angora & 1 year & 0,04 & 0,08 & 0,04 & 0,16 & 0,04 & 214,28 \\
\hline 7 & Persian & 2 years & 0,04 & 0,08 & 0,04 & 0,16 & 0,04 & 214,28 \\
\hline 8 & Birman & 2 years & 0,04 & 0,08 & 0,06 & 0,12 & 0,04 & 187,50 \\
\hline 9 & European & 3 years & 0,06 & 0,08 & 0,04 & 0,16 & 0,04 & 214,28 \\
\hline 10 & Persian & 2 years & 0,04 & 0,04 & 0,06 & 0,16 & 0,04 & 187,50 \\
\hline 11 & European & 1 year & 0,04 & 0,08 & 0,04 & 0,16 & 0,08 & 214,28 \\
\hline 12 & Persian & 2 years & 0,04 & 0,08 & 0,04 & 0,12 & 0,04 & 187,50 \\
\hline \multicolumn{3}{|c|}{ AVERAGE } & 0,043 & 0,073 & 0,045 & 0,150 & 0,051 & 196,92 \\
\hline \multicolumn{3}{|c|}{ Standard deviation } & 0,007 & 0,015 & 0,009 & 0,018 & 0,015 & 16,38 \\
\hline
\end{tabular}

Table 2. The values of the ECG components in cats obtained by other authors, compared with our results (seconds)

\begin{tabular}{ccccccc}
\hline Author & $\mathrm{P}$ & $\mathrm{P}-\mathrm{R}(\mathrm{P}-\mathrm{Q})$ & $\mathrm{QRS}$ & $\mathrm{Q}-\mathrm{T}$ & $\mathrm{T}$ & Heart rate \\
\hline Tilley L. et al., 2007 & 0,040 & $0,05-0,09$ & 0,040 & $0,12-0,18$ & - & $120-240$ \\
\hline Sarangi S. et al., 2016 & 0,040 & $0,05-0,09$ & 0,040 & $0,07-0,20$ & - & $160-220$ \\
\hline Camacho A. et al., 2010 & 0,040 & $0,05-0,09$ & 0,040 & $0,12-0,18$ & - & $120-240$ \\
\hline Ghiță M. et al., 2007 & 0,042 & 0,078 & 0,041 & 0,158 & 0,058 & $193-204$ \\
\hline Personal researches & $\mathbf{0 , 0 4 3}$ & $\mathbf{0 , 0 7 3}$ & $\mathbf{0 , 0 4 5}$ & $\mathbf{0 , 1 5 0}$ & $\mathbf{0 , 0 5 1}$ & $\mathbf{1 7 9 - 2 1 2}$ \\
\hline
\end{tabular}

\section{Conclusions}

In this research work, we demonstrated that the results obtained by us confirm the values acquired by other researchers in studies about evaluation of the ECG components duration. The values obtained in this research work can be used as reference values in ECG interpretation in cats.

Acknowledgments. This research did not receive any specific grant from funding agencies in the public, commercial, or not-for-profit sectors.

\section{References}

1. Camacho AA, Paulino D, Pascon Jr JPE, Teixeira AA (2010). Comparison between conventional and computerized electrocardiography in cats. Arquivo Brasileiro de Medicina Veterinária e Zootecnia, 62: 765-769.

2. Cotor G, Ghiță M (2014). Note de curs și lucrări practice de fiziopatologie specială. București: Editura Printech.
3. Ghiță M (2007). Înregistrarea electrocardiogramei și valorile parametrilor electrocardiografici la animalele domestic. Bucuresti: Editura Cartea Universitară.

4. Ghiță M,Cotor G, Brăslașu C, Botezatu R (2005). Considerații practice privind înregistrarea electrocardiogramei la pisică. Lucrări Științifice, Medicină Veterinară Iaşi, Ed. Ion Ionescu de la Brad, 48: 362-367.

5. Ghiţă M, Cotor G, Brăslaşu C, Botezatu R (2007). Studies on the duration of some ECG parameters in cats. Lucrari Ştiinţifice, Medicină Veterinară, Timişoara, XL: 393-396.

6. Tilley L, Francis S, Mark O, Sleepe M (2007). Manual of Canine and Feline Cardiology. (4th ed.). Missouri: Saunders.

7. Sarangi S, Mahapatra APK, Mohapatra S, Kundu AK (2016). Age-specific changes in electrocardiographic parameters in bipolar limb leads of conscious female native cats of Odisha. Veterinary World, 9: 147-150.

8. Wendy AW (2011). Cardiovascular disease in small animal medicine. UK: Manson Publushing Ltd, (Section 1). 